\title{
PENGEMBANGAN KURIKULUM, SILABUS DAN SATUAN ACARA PERKULIAHAN (SAP) DI PERGURUAN TINGGI AGAMA ISLAM
}

\author{
Syafruddin Nurdin \\ Jurusan Pendidikan Agama Islam, Fakultas Tarbiyah IAIN Imam Bonjol Padang \\ Korespondensi: Jln. Mahmud Yunus, Lubuk Lintah Padang, Sumatera Barat \\ e-mail: syaf.nurd2in@gmail.com
}

\begin{abstract}
Syllabus is a development of curriculum that contains synopsis, competency, indicator of topic/ sub-topic, and reference of a major. To apply curriculum well in a classroom, it is better to develop syllabus to become a lesson plan. Lesson plan consists of some components; Standard Competency, Basic Comptency, Indicator Competency, Lecture material and its description, learning experience (learning Strategy), medial learning tools, evaluation system, and reference. Lesson plan is a projection that will be done by lecturer in classroom.
\end{abstract}

Kata kunci: kurikulum, silabus, SAP

\section{PENDAHULUAN}

$\mathrm{P}$ enyusunan dan pengembangan silabus merupakan bagian integral dari pengembangan kurikulum dan sekaligus menjadi salah satu tugas penting dosen/staf pengajar di perguruan tinggi. Dalam silabus dimuat kerangka materi kuliah (bahan ajar) yang harus disampaikan dosen/staf pengajar kepada mahasiswa.

Membicarakan tentang penyusunan silabus, sebenarnya adalah memperbincangkan tentang rencana operasional kurikulum yang terdapat pada buku pedoman. Tingkat operasional kurikulum, pada dasarnya bertitik tolak atau berpijak pada tingkat konsepsi kurikulum yaitu asumsi yang mendasari suatu kurikulum. Dengan perkataan lain, perlu terlebih dahulu dipahami dasar pengembangan kurikulum sebagai landasan penyusunan dan pengembangan silabus. Selain dari itu, pengertian konsep kurikulum dapat memberikan arah bagi perbaikan kurikulum yang sedang diimplementasikan atau berlaku sekarang ini. Sekalipun makalah ini tujuan utamanya bukanlah untuk hal tersebut, tetapi hal ini perlu dikemukakan agar para penanggung jawab pendidikan, perencana dan pengembang kurikulum, guru-guru, dosen/ staf pengajar, serta pihak-pihak yang berkepentingan dengan masalah kependidikan dapat melihat beberapa dimensi bagi perbaikan kurikulum di masa datang.

Konsep yang mendasari pengembangan dan implementasi kurikulum adalah asumsi dasar tentang, paling kurang mencakup tiga hal pokok, yang menurut Tanner and Tanner (Tanner, Daniel dan Tanner, 1975 dalam Mohd Ansyar, 1982) merupakan "sumber" dan "pembentuk" kurikulum. Ketiga konsep dasar tersebut adalah asumsi tentang: (1) ilmu pengetahuan, (2) anak didik/ peserta didik (siswa/ mahasiswa), dan (3) masyarakat. Asumsi atau pandangan yang berbeda tentang ketiga penentu (determinan) kurikulum ini akan meng- 
arah kepada tujuan atau orientasi kurikulum yang berbeda-beda pula (Ansyar, 1982). Dengan perkataan lain, perbedaan asumsi mengenai ketiga penentu kurikulum ini berpengaruh terhadap arah pendidikan itu sendiri.

\section{KONSEP DAN PENGERTIAN KURIKULUM}

Untuk menyamakan persepsi dan pandangan kita mengenai kurikulum, terlebih dahulu penulis akan mengemukakan secara singkat tentang konsep dan pengertian kurikulum.

Kurikulum merupakan inti dari proses pendidikan, sebab di antara bidang-bidang pendidikan yaitu: manajemen pendidikan, kurikulum, dan layanan siswa, kurikulum merupakan bidang yang paling langsung berpengaruh terhadap hasil pendidikan. Dalam pengembangan kurikulum, minimal dapat dibedakan antara "disain kurikulum atau kurikulum tertulis (design, written, ideal, official, formal, document curriculum) dan implementasi kurikulum atau kurikulum perbuatan (curriculum implementation, curriculum in action, aktual curriculum, real curriculum)" (Nana Syaodih Sukmadinata, 2003: 1).

Disain kurikulum dapat bersifat menyeluruh, mencakup semua rancangan dan komponen kurikulum seperti dasar-dasar dan struktur kurikulum, sebara mata pelajaran, Garis-Garis Besar Program Pengajaran (GBPP), program tahunan/ semester, silabus, Satuan Pelajaran (SAP), rancangan pengembangan media, sumber dan alat evaluasi, tetapi bisa juga hanya berkenaan dengan asalah satu bentuk disain atau rancangan saja, umpamanya silabus atau GBPP.

Demikian juga dengan implementasi kurikulum, dapat meliputi seluruh kegiatan penerapan rancangan, seperti kegiatan pembelajaran, pembimbingan, pelatihan, kegiatan ko dan ekstra kurikuler, fields trips atau widya wisata, pengerjaan tugas-tugas, ulangan, ujian sampai dengan wisuda, atau hanya berkenaan dengan salah satu kegiatan saja seperti pembelajaran. Dengan demikian merupakan hal yang wajar apabila dalam masyarakat ada yang memandang kurikulum dalam arti yang luas (semua komponen rancangan dan implementasi) atau secara sempit, rancangan saja, itupun dibatasi lagi pada silabus atau GBPP.

Kurikulum memiliki pengertian yang cukup kompleks, dan sudah banyak didefinisikan oleh para pakar. Esensinya, kurikulum membicarakan proses penyelenggaraan pendidikan sekolah, berupa acuan, rencana, norma-norma yang dapat dipakai sebagai pegangan. Secara umum struktur kurikulum mempunyai empat komponen utama, yaitu: tujuan, materi/ bahan (organisasi isi), proses belajar mengajar, dan evaluasi.

Dalam arti sempit kurikulum ditafsirkan sebagai materi pelajaran, sedangkan menurut pengertian yang luas, kurikulum dikatakan sebagai keseluruhan program lembaga pendidikan. Spektrum di antara kedua kutub itu menafsirkan kurikulum sebagai perencana interaksi antara siswa dan guru untuk mencapai tujuan pendidikan (Miller and Seller, 1985: 3). Pengertian yang tidak terlalu luas dan tidak terlalu sempit, pada dasarnya merujuk pada perencanaan kegiatan belajar mengajar guna mencapai tujuan sekolah. Pengertian kurikulum yang berada pada spektrum ini antara lain dikemukakan oleh: Finch an Crunkilton (1984); Tanner and Tanner (1980); Eisner and Vallance (1974); Taba (1962); Alberty and Alberty (1962) dan Tyler (1949).

Dalam Undang-Undang nomor 20 tahun 2003 tentang Sistem Pendidikan Nasional, kurikulum diartikan sebagai... "Seperangkat rencana dan pengaturan mengenai tujuan, isi, dan bahan pelajaran serta cara yang digunakan sebagai pedoman penyelenggaraan kegiatan 
pembelajaran untuk mencapai tujuan pendidikan tertentu" (Sinar Grafika, 2003: 4).

Dari pengertian kurikulum di atas, secara eksplisit terlihat tiga komponen kurikulum, yaitu: tujuan, isi dan bahan pelajaran, serta cara atau metode yang digunakan sebagai pedoman penyelenggaraan KBM. Meskipun evaluasi tidak dinyakatan secara eksplisit, tapi rase cara yang digunakan sebagai pedoman penyelenggaraan kegiatan belajar mengajar secara implisit juga menyimpan arti tentang "evaluasi”. Karena, kegiatan belajar mengajar pada hakikatnya diawali dengan perencanaan, diiringi dengan pelaksanaan (implementasi) dan diakhiri oleh penilaian atau evaluasi. Jadi evaluasi merupakan bagian integral dari sebuah kegiatan belajar mengajar dan juga sekaligus merupakan salah satu komponen utama kurikulum.

Dengan demikian pengertian kurikulum yang terdapat dalam Undangundang Nomor 20 tahun 2003 sudah mencakup keempat komponen utama kurikulum, yaitu; tujuan, isi/bahan/materi, motede/cara, dan evaluasi.

\section{SILABUS MATA KULIAH DAN PENGEMBANGANNYA}

Mengembangkan Silabus dan Satuan Acara Perkuliahan (SAP) merupakan proses/langkah lanjutan dari pengembangan kurikulum. Pembahasan tentang soal silabus dan Satuan Acara Perkuliahan (SAP) tidak dapat dilepaskan dari proses pengembangan kurikulum secara keseluruhan (komprehensif).

Secara teoritik proses pengembangan kurikulum mengikuti lankahlangkah sebagai berikut:

Pertama, merumuskan tujuan (tujuan institusi/lembaga/sekolah/pelatihan dan sebagainya). Perumusan tujuan diawali dengan mengadakan analisis kebutuhan (need assessment), yaitu membaca, mempelajari, memahami, mengakomodasi dan mengapresiasi kebutuhan, tuntutan dan perkembangan yang terjadi ditengah-tengah masyarakat. Selain dari itu juga diperlukan mengantisipasi trend perkembangan ilmu pengetahuan, teknologi dan seni. Sehingga dengan demikian dapat diketahui kebutuhan pasar, lembaga pemakai lulusan (stakeholders) dan arah serta kecendrungan perkembangan ilmu pengetahuan, teknologi dan seni dimasa depan. Perumusan tujuan yang betul-betul memperhatikan, mengakomodasi dan mengapresiasi hasil need assesment, pada gilirannya akan dapat menghasilkan kurikulum yang memiliki relevansi tinggi, baik dengan kebutuhan peserta didik, masyarakat, maupun dengan kebutuhan pembangunan dan perkembangan ilmu pengetahuan, teknologi dan seni. Dengan demikian lulusan (output) lembaga pendidikan bisa berguna secara fungsional di tengah-tengah masyarakat.

Di samping itu, perumusan tujuan institusional tidak boleh lepas dan menjauh dari rumusan tujuan pendidikan nasional. Artinya, rumusan tujuan institusional harus mengacu dan berorientasi kepada tujuan pendidikan nasional yang telah ditetapkan oleh Undang-Undang. Sehingga dengan demikian setiap lembaga pendidikan yang ada dibumi persada ini diharapkan dapat menghasilkan lulusan (output) yang sesuai dengan visi, kisi dan karakteristik institusi/lembaga dan sejalan dengan cita-cita yang termaktub dalam undang-undang nomor 20 tahun 2003 tentang sistem pendidikan nasional yitu,..."manusia yang beriman dan bertaqwa kepada Tuhan yang Maha Esa, berakhlak mulia, sehat, berilmu, cakap, kreatif, mandiri dan menjadi warga negara yang demokratis serta bertanggung jawab (UU No. 20 Tahun 2003, Bab II, Pasal 3)".

Dengan adanya perumusan tujuan yang jelas dan spesifik, akan tergambar "profil lulusan" sebuah lembaga pen- 
didikan (jurusan atau program studi). Program studi "X" akan menghasilkan lulusan yang memiliki kemampuan (kompetensi) dalam bidang apa? Misalnya, prodi " $X$ " akan menghasilkan lulusan yang memiliki keahlian dalam bidang ilmu aqidah dan filsafat.

Kemudian, pada langkah kedua diidentifikasi kompetensi (kemampuan) yang harus dimiliki para lulusan setelah mengikuti proses pendidikan disebuah lembaga. Artinya, kemampuan-kemampuan (kompetensi) apa saja yang mesti ada pada diri lulusan setelah ia menyelesaikan studi/kuliah pada sebuah lembaga/institusi pendidikan. Contohnya, kemampuan-kemampuan (kompetensi) apa saja yang harus dimiliki oleh seorang lulusan jurusan PAI dapa fakultas Tarbiyah IAIN. Lulusan jurusan PAI Fakultas Tarbiyah hatus memiliki kompetensi: (1) Mangajarkan PAI dan Ilmu-ilmu Agama Islam pada sekolah umum, Madrasah dan Pondok Pesantren, (2) Melaksanakan Supervisi atau Pengawasan Pendidikan Agama pada Sekolah Umum, Madrasah dan Pondok Pesantren. Apa sebenarmnya yang mendasari penetapan dua kompetensi di atas? Pertanyaan ini jawabannya adalah "rumusan Profil lulusan" yang telah diformulasikan sebelunnya, yaitu" (1) Guru mata pelajaran Pendidikan Agama Islam (PAI) pada sekolah umum, (b) Guru mata pelajaran ilmu-ilmu agama Islam pada Madrasah dan Pondok Pesantren (c) Supervisor atau Pengawas Pendidikan Agama. Bertolak dari gambaran profil lulusan itulah muncul dua kompetensi (utama) yang telah dikemukakan di atas.

Selanjutnya, sebagai langkah ketiga, adalah menentukan (mengidentifikasi) pengetahuan, nilai-sikap dan keterampilan (cognitive, affective and psychomotoric) apa saja yang diperlukan untuk menghasilkan sejumlah kompetensi (utama, pendukung dan lainnya) yang telah ditetapkan di atas. Misalnya, untuk menghasilkan kompetensi utama "mengajarkan PAI dan Ilmu-ilmu Agama Islam" memerlukan sejumlah pengetahuan, nilai-sikap dan keterampilan. Pengetahuan dan keterampilan tentang bagaimana merumuskan TPK yang spesifik, terukur, operasional dan observable dalam menyusun sebuah Satuan Pembelajaran. Keterampilan mengelola kelas dan mengajukan pertanyaan-pertanyaan yang tepat kepada siswa/ mahasiswa dalam pembelajaran. Pengetahuan dan keterampilan dalam menggunakan metode dan media pembelajaran. Pengetahuan, nilai-sikap dan keterampilan dalam memperlakukan siswa/ mahasiswa sebagai makhluk unik, yang memiliki perbedaan antara yang satu dan lainnya, baik pertumbuhanperkembangan ataupun karakteristik lainnya (individual differences). Dan banyak lagi pengetahuan nilai-sikap serta keterampilan yang memberik sumbangan untuk menghasilkan "kompetensi utama" tersebut di atas.

Berikutnya, langkah keempat adalah memilih dan menentukan "mata kuliah" yang akan diajarkan. Mata kuliah-mata kuliah apa saja yang dapat menghasilkan pengetahuan, nilai sikap dan keterampilan bagi mahasiswa, sehingga mereka memiliki kompetensi seperti ditetapkan pada langkah ketiga di atas. Ini berarti, bahwa pemilihan dan penentuan mata kuliah haruslah didasari dan disesuaikan dengan tujuan lembaga dan kompetensi (utama) yang harus dimiliki oleh lulusan setelah ia menamatkan studinya. Bukan atas dasar interest dan kepentingan sepihak, diulangi bukan atas dasar interest dan kepentingan sepihak. Hal ini hendaknya menjadi perhatian pimpinan lembaga dalam melakukan pengembangan kurikulum dan silabus mata kuliah pada masing-masing jurusan dan program studi. Kemudian, mata kuliah-mata kuliah yang telah ditentukan/ ditetapkan tersebut disusun dan dituangkan ke 
dalam sebuah Struktur Program Kurikulum (SPK), yang menggambarkan kelompok, posisi/ kedudukan, bobot SKS, alokasi waktu, sebaran mata kuliah, dan lain-lainnya.

Setelah langkah keempat tersebut barulah beranjak kepada penetapan dan penentuan siapa yang akan memegang apa (langkah kelima). Dengan ini dimaksudkan adalah menetapkan dosen/ staf pengajar yang paling tepat (relevan) untuk mengajarkan sebuah mata kuliah yang betul-betul sesuai dengan disiplin ilmu yang dimilikinya. Dalam istilah lain agaknya sering dikatakan sebagai the right man on the right place, yaitu menempatkan seseorang sesuai pada tempatnya. Ini pun perlu mendapat perhatian pimpinan lembaga, karena fenomena yang terlihat selama ini lebih banyak terjadi di perguruan tinggi ada mata kuliah yang tidak diajarkan oleh ahlinya, tapi lebih karena hubungan baik, klik, dan pertimbangan-pertimbangan non akademis, sehingga akhirnya berujung dengan minim dan rendahnya hasil belajar (kompetensi) yang diperoleh mahasiswa dalam perkuliahan. Padahal setiap mata kuliah itu memiliki karakteristik tersendiri, baik dari segi penguasaan substansi materi, maupun dari sudut penguasaan metodologi pembelajarannya.

Setelah menyelesaikan langkah kelima di atas, sampailah kita pada tugas untuk mengembangkan silabus, yang pada dasarnya diawali dengan perumusan tujuan mata kuliah atau kompetensi yang diharapkan dikuasai oleh mahasiswa yang mengikuti suatu mata kuliah tertentu, penentuan topik/ pokok bahasan, penentuan keluasan dan kedalaman materi (scope), urutan mana yang harus dahulu dan mana yang kemudian (sequence), serta referensi dan sebagainya.
PENGEMBANGAN

SILABUS MATA KULIAH

Agar kurikulum dapat diwujudkan menjadi pengalaman belajar yang bermakna bagi peserta didik, implementasi kurikulum harus dipandang sebagai bagian tak terpisahkan dari kurikulum itu sendiri. Penyusunan dan pengembangan silabus mata kuliah di perguruan tinggi merupakan usaha perencanaan implementasi sedemikian rupa, sehingga isi/ materi/ bahan/ konten, lingkungan belajar, sumber belajar, alat bantu, dan lain-lain yang direncanakan pada silabus ditransformasikan menjadi pengalaman belajar mahasiswa, sesuai tujuan yang telah dirumuskan. Secara tradisional (sesuai dengan "ontologi superatural", yang melihat ilmu pengetahuan final dan mutlak benar, karena itu tidak dapat dirubah), orientasi perkuliahan diarahkan kepada transfer ilmu pengetahuan dan informasi sebanyak mungkin kepada mahasiswa. Oleh karena itu, silabus juga disusun sejalan dengan pandangan di atas, agar pemindahan ilmu dan informasi kepada mahasiswa dapat dilakukan dengan baik. Silabus yang berorientasi kepada penerimaan konten ini (content learning) cenderung menciptakan suasana belajar otokratik, kurang memberi kesempatan bagi argumentasi dan diskusi antara dosen dan mahasiswa. Situasinya didominasi oleh komunikasi satu arah, dimana dalam perkuliahan (pembelajaran) dosen yang tampak lebih banyak aktif (teacher centered). Dipandang dari kacamata Bloom (taxonomi Bloom), tenaga, sarana, dan lain-lain agar mahasiswa mengetahui ilmu pengetahuan dan informasi, adalah merupakan tingkat belajar yang paling rendah saja (low level knowledge).

Pada kurikulum yang bedasarkan ontology manusia yang menganggap ilmu pengetahuan sebagai buatan manusia belaka, karenanya tidak mutlak benar, dapat berubah, serta terbuka bagi verifikasi publik. Silabus mata kuliah 
tidak hanya difokuskan pada tingkat mengetahui saja, tetapi juga mencakup tingkat-tingkat yang lebih tinggi dari aspek kognitif (misalnya evaluasi), malah termasuk aspek lain yang relevan (afektif dan psikomotorik). Aspek kognitif menurut Bloom terdiri atas enam tingkatan, yaitu: (a) pengetahuan, (b) pemahaman, (c) penerapan/aplikasi, (d) Analisis, (e) sintesis, dan (f) evaluasi (Nasution, 1989: 66). Jadi, artinya bisa sampai ke tingkat evaluasi.

Tujuan utama perkuliahan yang berorientasi proses pengembangan ilmu itu sendiri bukan untuk menjadikan mahasiswa serba tahu dalam bidangnya (karena hal itu tidak mungkin dapat dilaksanakan oleh dosen dengan sempurna), tetapi terutama untuk mendorong mahasiswa agar mampu belajar sendiri, ikut meneruskan proses rekonstruksi ilmu dan untuk menambah khazanah ilmu itu sendiri, karena dengan menyusun tata cara ilmiah kita tidak hanya dibantu untuk memahami ilmu itu secara memadai, tapi kita pun juga dapat menyumbangkan isi baru.

Dengan demikian konten yang dipelajari melalui dosen ataupun melalui sumber belajar lainnya bukanlah merupakan tujuan (end), tetapi merupakan cara/metode (means) bagi pengembangan ilmu itu sendiri buat pemecahan masalah di masyarakat. Ini berarti kurikulum berorientasi proses adalah pemanfaatan tenaga, sarana, dan waktu untuk mendorong belajar sehingga mahasiswa mampu belajar secara maksimal dan juga untuk belajar (to learn how lo learn) agar mampu belajar secara mandiri.

Belajar mandiri dimaksudkan bukanlah berarti belajar tanpa bimbingan, tanpa dosen secara acak-acakan dari semua terserah pada mahasiswa saja. Malah belajar mandiri memerlukan perencanaan yang matang sehingga perbedaan-perbedaan individual mahasiswa, seperti kecepatan belajar, perhatian, cara belajar dan perbedaan kemampuan intelektual, dan lain-lain diperhitungkan dengan seksama. Dalam menyusun dan mengembangkan silabus perlu memperhatikan sinopsis mata kuliah, apakah sinopsis itu berorientasi kepada konten saja, kurang berorientasi kepada proses, atau ada yang tumpang tindih (overlapping) antara mata kuliah yang berkaitan/ berhubungan, atau karena kreditnya terlalu sedikit disebabkan orientasi mata kuliah itu terlalu "content oriented".

Di samping itu, perlu juga dicermati, apakah silabus yang sedang diberlakukan atau yang akan disusun hanya mengajar mahasiswa untuk mampu menguasai konten saja, belum membekali mahasiswa tersebut agar mereka dapat pula belajar proses.

Sebagaimana telah diungkapkan di atas, bahwa silabus merupakan pengembangan dan jabaran dari kurikulum, yang berisikan sinopsis mata kuliah dari kerangka materi pelajaran/perkuliahan (topik inti/pokok bahasan) yang harus diajarkan dan dikuasai oleh mahasiswa.

Dalam silabus terdapat scope and sequence kurikulum. Scope ialah ruang lingkup, keluasan, dan kedalaman bahan/materi perkuliahan. Sedangkan sequence adalah urut-urutan bahan/materi perkuliahan yang akan diajarkan. Selain dari itu, silabus biasanya dilengkapi dengan referensi atau bukubuku sumber, baik yang wajib atau pun anjuran.

Silabus Kurikulum Berbasis Kompetensi (KBK) terdiri atas komponenkomponen, sebagai berikut:

1. Identitas

Identitas memuat nama, kode, komponen dan bobot mata kuliah, fakultas, jurusan / program studi

2. Sinopsis Mata Kuliah

Sinopsis mata kuliah adalah merupakan pernyataan singkat yang berisikan garis-garis besar materi perkuliahan atau rangkuman pokok 
bahasan/sub pokok bahasan/topik dari satu mata kuliah.

3. Kompetensi Mata Kuliah Kompetensi Mata Kuliah merupakan pernyataan tentang hasil belajar (learning outcomes) berupa: pengetahuan, nilai-sikap, dan keterampilan yang diperoleh dun dikuasai mahasiswa setelah mengikuti mata kuliah tertentu.

4. Indikator Kompetensi

Indikator kompetensi merupakan jabaran karakteristik suatu kompetensi yang secara spesifik dapat dijadikan ukuran untuk menentukan dan menilai ketercapaian hasil belajar.

5. Topik

Topik dan sub topik merupakan judul/sub judul yang mencerminkan isi atau materi kuliah yang konsisten dengan setiap kompetensi dasar. Dengan kata lain dapat pula diartikan bahwa topik/sub topik adalah pokok-pokok materi kuliah yang harus dipelajari oleh mahasiswa sebagai sarana pencapaian kompetensi.

6. Referensi

Referensi adalah sumber kepustakaan berupa buku-buku atau sumber materi kuliah lainnya yang digunakan dalam pokok bahasan/topik/sub topik.

\section{PENGEMBANGAN ACARA PERKULIAHAN (SAP)}

\section{Pendahuluan}

Satuan Acara Perkuliahan (SAP) merupakan proyeksi kegiatan (aktivitas) yang akan dilakukan oleh guru/dosen atau staf pengajar dalam prose pembelajaran di kelas. Oleh karenanya, SAP merupakan bagian integral yang tidak dapat dilepaskan dari "pembelajaran". Ini berarti, bahwa setiap guru/dosen yang akan melaksanakan pembelajaran (perkuliahan) terlebih dahulu harus membuat SAP.

Pembelajaran (perkuliahan) merupakan interaksi edukatif yang dilakukan oleh mahasiswa dengan dosen dan sumber belajar lainnya di dalam suatu situasi tertentu.

Melaksanakan pembelajaran bukanlah suatu pekerjaan yang mudah dan dapat terjadi seperti membalikkan telapak tangan, akan tetapi "pembelajaran"' merupakan kegiatan yang mesti direncanakan dan diatur sedemikian rupa menurut langkah-langkah tertentu. Sehingga pelaksanaannya dapat mencapai hasil yang diharapkan.

Berkenaan dengan hal yang dikemukakan di atas, Nasution (1989: 2) menyatakan sebagai berikut:

Agar bahan pelajaran dapat disajikan kepada siswa/mahasiswa dalam jam pelajaran tertentu guru/staf pengajar harus membuat persiapan pelajaran yang dilakukan berdasarkan pedoman instruksional itu. Tiap pengajar harus membuat persiapan pelajaran sebelum ia dengan penuh tanggung jawab memasuki kelas. Dengan tiap pengajar dimaksud guru TK, SD, SM, tetapi juga dosen termasuk guru besar perguruan tinggi. Mengajar adalah tugas yang begitu kompleks dan maha sulit, sehingga tidak dapat dilakukan dengan baik oleh siapapun tanpa persiapan, sekalipun ia telah berpengalaman bertahun-tahun.

Pernyataan yang dikemukakan Nasution di atas, memberi implikasi bahwa:

a. Mengajar merupakan pekerjaan dan tugas yang kompleks dan sulit. Oleh karena itu, tugas dan pekerjaan tersebut memerlukan persiapan dan perencanaan yang baik, sehingga dapat mencapai hasil yang diharapkan.

b. Mengajar merupakan pekerjaan yang harus dipertanggungjawabkan (akuntabilitas). Dengan demi- 
kian ia memerlukan perencanaan dan persiapan yang mantap dan dapat dinilai pada akhir proses pembelajaran.

c. Mengajar merupakan tugas mengorganisasi dan mengatur jalannya proses pembelajaran. Oleh karena itu, setiap guru/dosen perlu membuat persiapan pengajaran, satuan pembelajaran atau SAP.

Senada dengan pendapat Nasution tersebut, Waini Rasyidin (1988 : 63-64) dalam disertasinya mengungkapkan pula, sebagai berikut:

Perencanaan adalah penataan langkah-langkah ke arah tujuan. Perencanaan sangat diperlukan oleh guru/staf dosen/pengajar, karena alokasi sumber, terutama jatah waktu yang terbatas.

Adapun perencanaan itu oleh guru/dosen/staf pengajar, meskipun tidak ditulis lengkap, seyogianya meliputi: (1) penentuan tujuan mengajar, (2) pemilihan materi sesuai dengan waktu, (3) strategi optimum, (4) alat dan sumber,

(5) kegiatan belajar siswa/mahasiswa, dan (6) evaluasi.

Perencanaan pengajaran atau desain instruksional membantu guru/ dosen mengarahkan langkah dan aktivitas atau perilaku yang akan dilaksanakan dalam pembelajaran dalam mencapai tujuan. Sekurang-kurangnya dalam desain instruksional yang diwujudkan dalam bentuk Satuan Pembelajaran (SP) atau Satuan Acara Perkuliahan (SAP) itu tercakup unsur-unsur; tujuan pembelajaran, materi/bahan pelajaran yang akan diajarkan, strategi belajar-mengajar yang akan dikembangkan, dan prosedur evaluasi yang dilakukan dalam menilai hasil belajar siswa/ mahasiswa. Sebagaimana ditegaskan George Brown (1978: 23-24), berikut ini:

Key question in planning:

a. What kinds of thing do you want the pupil learn? (skill, facts, concepts, attitudes, values); b. What are you precise instructional objective?

c. What is the most appropriate sequence of topics and tasks ?

d. What are the most appropriate methods?

e. How should the teaching and learning be evaluated ?

\section{Pengertian}

Satuan Acara Perkuliahan (SAP) diartikan sebagai program pengajaran yang meliputi satu atau beberapa pokok bahasan/topik untuk diajarkan selama satu kali atau beberapa kali pertemuan. SAP memberikan petunjuk secara rinci tentang sipnosis, kompetensi mata kuliah, indikator kompetensi, pokok bahasan/topik, strategi pembelajaran, media dan alat, evaluasi, estimasi waktu dan kepustakaan.

\section{Fungsi}

Perencanaan pengajaran yang dipersiapkan guru/dosen pada dasarnya berfungsi : (1) menentukan arah kegiatan pembelajaran, (2) memberi isi dan makna tujuan, (3) menentukan cara bagaimana mencapai tujuan yang ditetapkan, dan (4) mengukur seberapa jauh tujuan itu telah tercapai dan tindakan apa yang harus dilakukan apabila tujuan belum tercapai.

Dengan demikian jelas bahwa, SAP berfungsi sebagai pedoman bagi dosen/staf pengajar agar dapat mengajar dengan baik, tanpa kekhawatiran keluar dan menyimpang dari tujuan pembelajaran, ruang lingkup materi, strategi pembelajaran dan sistem evaluasi yang seharusnya.

\section{Langkah-Langkah Pengembangan SAP}

Dalam Satuan Acara perkuliahan (SAP) terdapat sejumlah komponen yang dikembangkan, sebagai berikut: 


\section{Identitas SAP}

Mengisi/identitas SAP adalah menuliskan nama mata kuliah, judul pokok bahasan/topik, alokasi waktu/SKS, jurusan/prodi.

\section{Standar Kompetensi}

Menentukan/merumuskan tentang pengetahuan, keterampilan, dan sikap yang dipersyaratkan untuk melak-sanakan tugas/pekerjaan tertentu sesuai dengan kriteria perfor-mansi dalam standar yang ditetapkan.

\section{Kompetensi/Kemampuan Dasar}

Menentukan/merumuskan tentang pengetahuan, keterampilan, dan sikap minimal yang harus dikuasai dan dapat diperagakan oleh mahasiswa (setelah mengikuti pembelajaran/perkuliahan).

Indikator Kompetensi

Merumuskan indikator kompetensi, yaitu indikator yang merupakan jabaran karakteristik suatu kompetensi yang secara spesifik dapat dijadikan ukuran untuk menentukan dan menilai ketercapaian hasil belajar.

Materi Pelajaran dan Uraiannya

Menentukan pokok-pokok materi serta uraiannya (analisis materi) yang harus dipelajari mahasiswa sebagai sarana pencapaian kemampuan dasar.

Pengalaman Belajar

Menentukan pengalaman atau kegiatan yang perlu dilakukan oleh mahasiswa untuk menguasai kemampuan dasar atau materi pembelajaran.

Sistem Penilaian (Evaluasi)

Sistem penilaian meliputi bentuk penilaian berupa, : (1) tugas mandiri, (2) tugas terstruktur, (3) tugas kelompok, (4) partisipasi kelas (aktivitas diskusi, presentasi kelas, dll). (5) ujian tengah semester, (6) ujian akhir semester, dan (7) penilaian "portofolio'".

Penilaian harus dilakukan secara berkelanjutan dan terintegrasi dengan memperhatikan keutuhan kompetensi yang mencakup ranah kognitif, psikomotorik, dan afektif.

\section{Referensi}

Menentukan referensi berupa buku-buku atau sumber materi yang digunakan dalam setiap pokok bahasan/sub pokok bahasan/topik. Penulisannya dapat dimulai dari: nama pengarang, tahun terbit (dalam kurung), judul buku (boleh diketik miring), nama kota, dan penerbit.

\section{PENUTUP}

Pengembanagn kurikulum mengikuti langkah dan proses sebagai berikut; pertama adalah merumuskan tujuan institusi (lembaga), yang diawali oleh need assessment. Kemudian, penentuan/identifikasi kompetensi, identifikasi pengetahuan, nilai-sikap dan keterampilan. Selanjutnya, diteruskan dengan menyusun Struktur Program Kurikulum, yang disusul dengan penentuan mata kuliah, sebaran dan alokasi waktunya. Kemudian ditentukan dosen/staf pengajar yang akan memegang mata kuliah sesuai dengan bidang keahliannya.

Sebagai jabaran dan pengembangan dari kurikulum (written curriculum), disusun dan dikembangkanlah Silabus, yang memuat komponen-komponen, sebagai berikut; sinopsis mata kuliah, kompetensi mata kuliah, indikator kompetensi, topik/sub topik, dan referensi.

Agar kurikulum dapat diimplementasikan dengan baik dalam perkuliahan di kelas, maka silabus perlu dijabarkan/dikembangkan menjadi Satuan Acara Perkuliahan (SAP). SAP memuat komponen; standar kompetensi, kompetensi dasar, indikator kompetensi, materi perkuliahan dan uraiannya, pengalaman belajar (strategi pembelajaran), media/alat pembelajaran, sistem penilaian, dan referensi.

SAP merupakan proyeksi kegiatan atau aktivitas yang akan dilakukan oleh dosen dalam perkuliahan. 


\section{DAFTAR RUJUKAN}

Ansyar, M. (2003). Hakekat Kurikulum Berbasis Kompetensi: Implikasinya pada Kurikulum Pendidikan Tinggi. (Makalah Seminar Kurikulum Berbasis Kompetensi IAIN Imam Bonjol Padang).

Brady, Laurie. (1992). Curriculum Development. New York: Prentice Hall.

Brown, George. (1978). Micro Teaching. A Program of Teaching Skill. London: Methuen and Co Ltd.

A. Mulyasa. (2002). Kurikulum Berbasis Kompetensi: Konsep, Karakteristik dan Implementasi. Bandung: Remaja Rosdakarya.

Fasli Jalal. (2002). Sambutan Pembukaan Seminar Nasional KBK di UNP. Padang.

Hamid Hasan. (2002). Hakekat Kurikulum Berbasis Kompetensi. (Makalah Dalam Seminar Nasional KBK UNP).

Nana Syaodih Sukmadinata. (1997). Pengembangan Kurikulum: Teori dan Praktek. Bandung: Remaja Rosdakarya.

. (2U03). Dasar-Dasar Pengembangan Kurikulum Perguruan Tinggi. (Makalah Dalam Lokakarya Pengembangan Kurikulum Berbasis Kompetensi IAIN Sunan Gunung Djati Bandung).

Nasution, S. (1989). Kurikulum dan Pengajaran. Jakarta Bina Aksara.

Rose, Colin \& Malcom J. Nicholl. (2002). Accelerated Learning For the $21^{\text {st }}$ Century. Bandung: Nuansa.

Sinar Grafika. (2003). Undang-Undang SISDIKNAS (Sistem Pendidikan Nasional) 2003 (UU RI No. 20 Tahun 2003). Jakarta.

Soedijarto. (1993). Memantapkan Sistem Pendidikan Nasional. Jakarta: PT. Gramedia Wirasarana.

Tyler, Ralph W. (1949). Basic Principle of Curriculum and Instruction. Chicago: Chicago Press 